\title{
MASTER
}

\section{EVALUATION OF ONE-YEAR RESUXTS OF THE FULL-FACE RESPIRATOR QUANTITATIVE MAN-TEST FITTING PROGRAM AT THE LAWRENCE LIVERMORE LABORATORY}
B. J. Held
J. Crose
K. P. Ellis
C. P. RIchards
R. Rodriquea

Decenber 8, 1976

Prepared for U.S. Energy Research \& Development Administralion under contract Nc W-7405-Eng-48
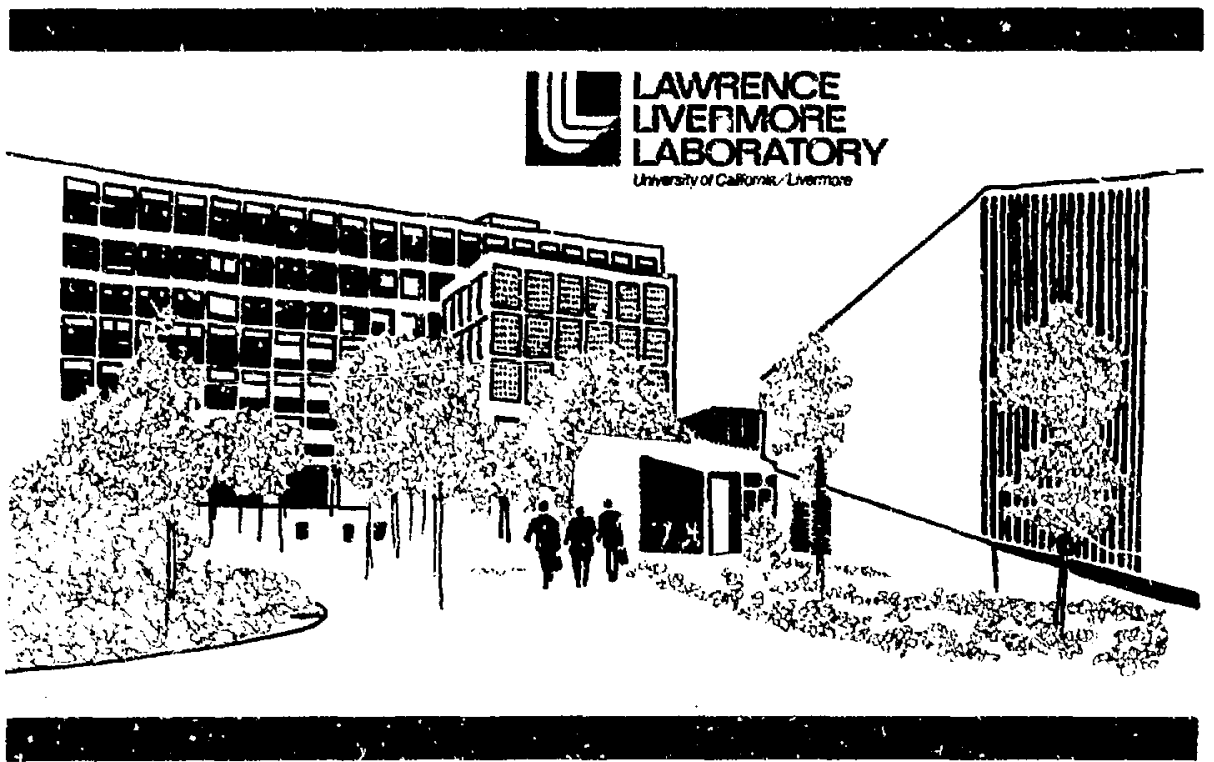


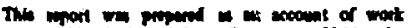

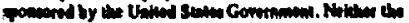

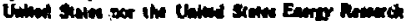

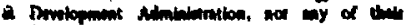

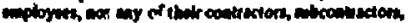

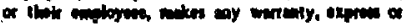

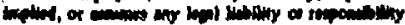

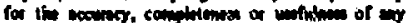

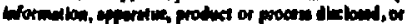

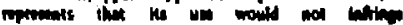

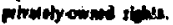

\section{MOTCE}

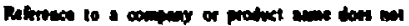

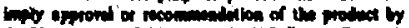

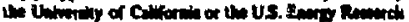

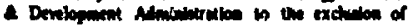

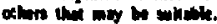

Finted in the United stam of Anerica Aveltath from

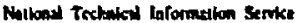

US. Deputeneal of Commentive

52as pout Royal koed

Spronfreld. VA 22161

Pike: Atimind Cop's : Mictorikte $\$ 300$

\begin{tabular}{|c|c|c|c|}
\hline$P=1$ & onstin & menese & Dann \\
\hline 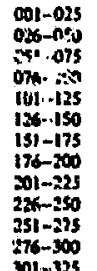 & $\begin{array}{l}\$ 3.50 \\
4.00 \\
4.50 \\
5.00 \\
5.00 \\
6.00 \\
6.75 \\
7.50 \\
7.15 \\
8.00 \\
9.00 \\
9.25 \\
9.75\end{array}$ & 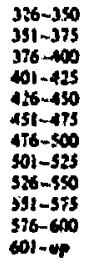 & $\begin{array}{l}1000 \\
1050 \\
10.75 \\
11.00 \\
11.75 \\
12.00 \\
12.50 \\
12.75 \\
13.00 \\
13.50 \\
13.75\end{array}$ \\
\hline
\end{tabular}

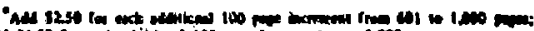

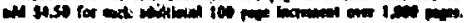




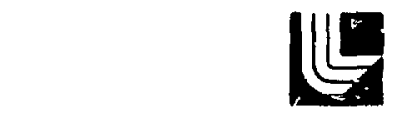

I_AWRENCE IJVERMORE I_AEORATORY

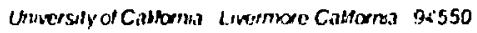

EVALUATION OF ONE-YEAR RESULTS OF THE FULL-FACE RESPIRATOR QUANTITATIVE MAN-TEST FITTING PROGRAM AT THE LAWRENCE LIVERMORE LABORATORY

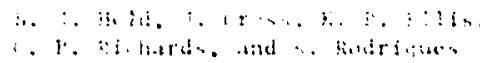

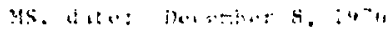

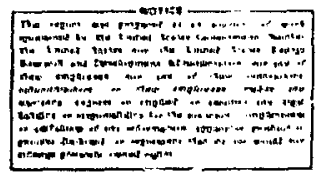




\title{
EVALUATION OF ONE-YEAR RESULTS OF THE FULL-FACE RESPIRATOR QUANTITATIVE MAN-TEST FITTING PROGRAM AT THE LA WRENCE LIVERMORE LABORATORY
}

\begin{abstract}
In August 1975, Lawrance Livermote laboratory began to quantitatively fit ail employees who are or may be required to wear any type of full-face respleitor. After one year, 305 emplovees hive been fitced. A total of 1362 cests weras made, uslug seven molces of iull-face resplrators. of the 30 's employees fitted, 284 were cested using nore than one make of full-fics mask.

All employees fitted could get a mixfmum usc I Imdt (Mt).) of at least 100. H: has a stul. of 100 to 499 on at le.lst "ne of the makes of misks

tested, $11 \%$ had an MUL of 500 to 999. 13\% had an MUL of 1000 to 1999. $24 \%$ had an MUl. of 2000 to 4999. and 44\% had an MUl greater than 5000. These numbers were derived us $1 \mathrm{ng}$. the average of the peal leakages occurring during each of six exerclses performed while wearing each mask. If the overall average leakage occurring during the six exercises rather than the poak average Is used in the calculat lons, $90 \%$ of the employees rould obtain an MLL over i000 on ac leasi one malie of mask.
\end{abstract}

\section{Introduction}

Al! personnel at Lawrence livermore Laboratory who wear or might have occaston to wear any type of full-face rospliatery protect: device are annuslly screened by the Medical Department for auch usage. After medical approval is granted, these coployees are then iven a quantitative min-test fitting to find out which makes of full-face raspiratora will five them an satisfactory facepleceto-face seal.

The criterion for satisfactory seal at h.t. has been that the integrated average leakage does not exceed $0.5 \%$ while the test subject performs a series of $\mathrm{s} 1 \mathrm{x}$ exerclses, and that the peak leakage during any one or more ct tiso $-1 \times$ exerclges does not exceed 1.0\%. A maximum use 1 indt (MUL). of $100 \mathrm{is}$ then used for the

$\star$ Maximu Use Limit (MUL) for a resplrator is a number which is the multiple of the permissible timeweighted average or excursion limit for coxic materials or the MPC for rasloactive materiais, and is obcained by dividing 100 by the percent leakage:

(uv). $=\frac{100}{7 \text { l.akage }}$. 
full-face respirator whenever the facepiece is under negative pressure. Further details on the fitting program can be found elsewhere. 1

This report is intended to evaluate the quantitative man-test fitting program results, the different makes of facepieces used in the program in regard to their fitting characteristics, and the program itself.

\section{Equipment and Procedures}

The number of facepieces with which a person is fitted will depend on whether that person requires the use of air-purifying, supplied-air, self-contained breathing apparatus, or any two or all three tipes. For those people requiring the use of only afr-purffying full-face respitators, the fitting tests are generally run with the MSA Clearvue, the MSA vitravue, the Acme, and the Nelsh masks. If the use is limited to self-contained breathing apnaratus (SCBA), tire fitting tests are generally conducted using the NSA Clearvue, the MSA Uitravue, the 6000 Series Scottoramic "old" style unask and the 9000 Series scottoramic "new" style mask. Toward the end of the first year of fitcing, the Survivalr sillcone mask was added to those being fitted with SCRA masks, for information only, altirough this mask is not belng used at hawrence lifvermore lathoratory (LLL). Flinres; 1 through 7 show the different masks used in the fitting progran. The ficting cests are conduced In a chamber contalning air-generated polydlsperse dioctylphthalate nist having a mass median aerodynamic diameter of between 0.6 tr 0.7 micrun. in alr Techniques Incorporated photometer. Nodel TDh-2ti, connected to a recorder, is used for measuring the facepiece teaking (see Fig. 8 ). A complate description of the lestings equipmeat is piven elscewhere.

for saich mask beine fitted, the test subject is isked to perform the following six exercises: '1) nurmal breathing. (2) deep breathing. (3) turning head slowl: from side wo slde, (4) nodding head slowly up and down, (5) reciting the alphabet, and (6) alternately smiling and frowning. 
F1g. 1. Acme full-face respirator.
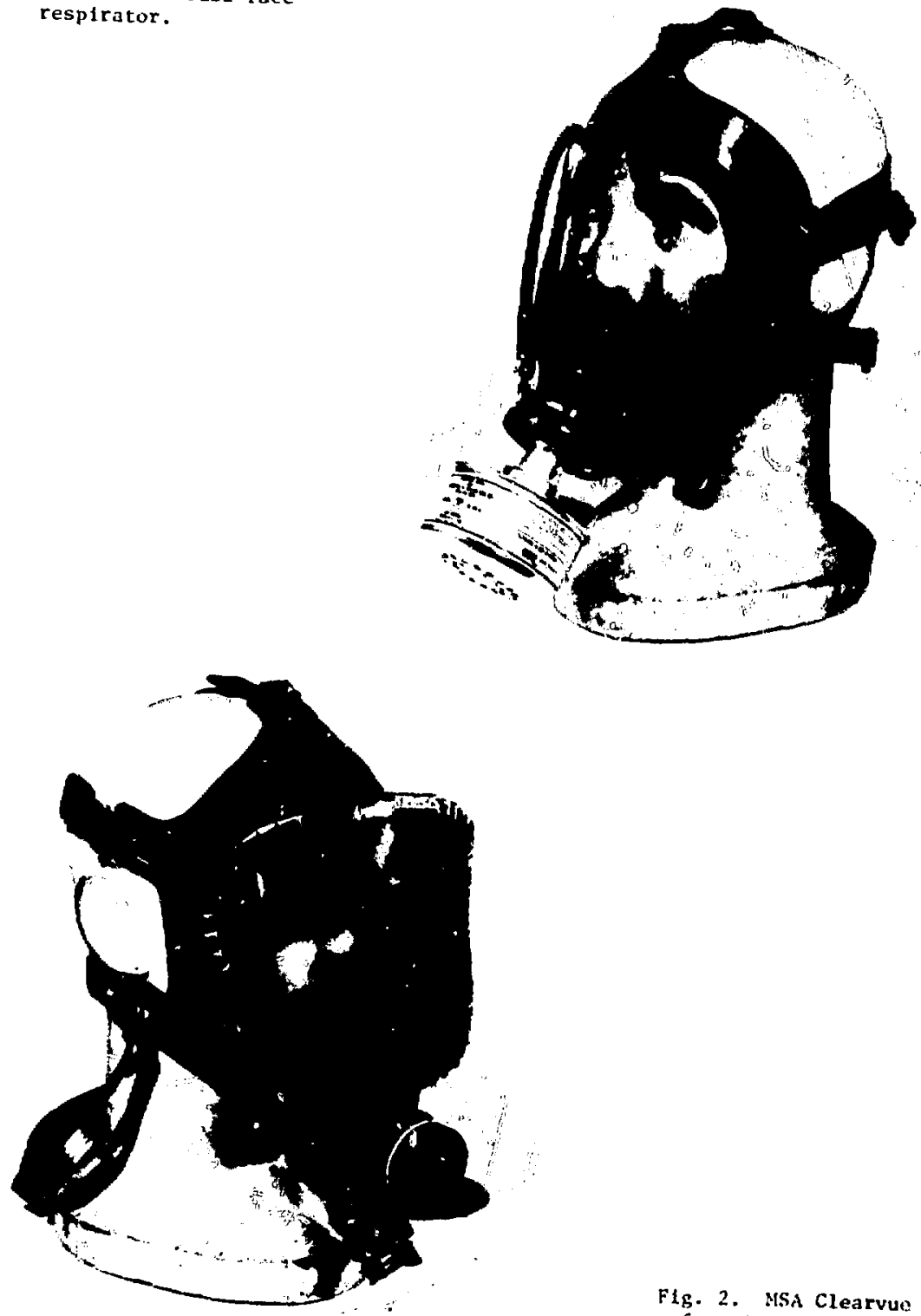

Flg. 2. MSA Clearvue faceplece. 


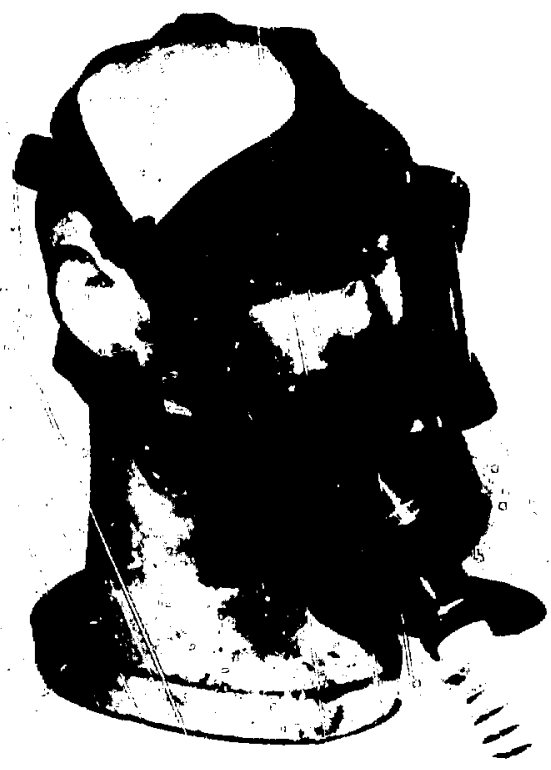

Fig. 3. MSA UItravue faceplece.

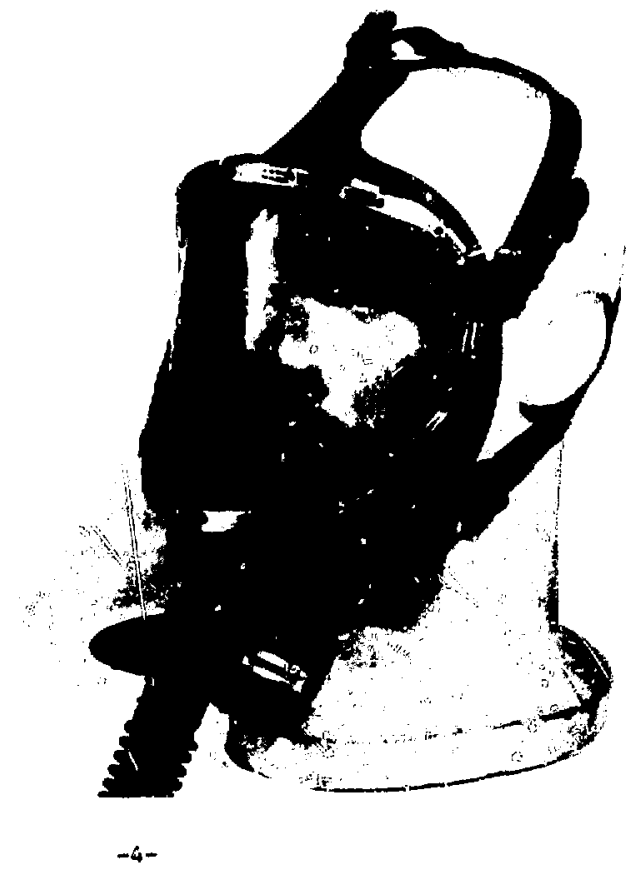

Fig. 4. Scottoramic faceplece - new type. 
Fig. 5. Survivalr tacepiece.
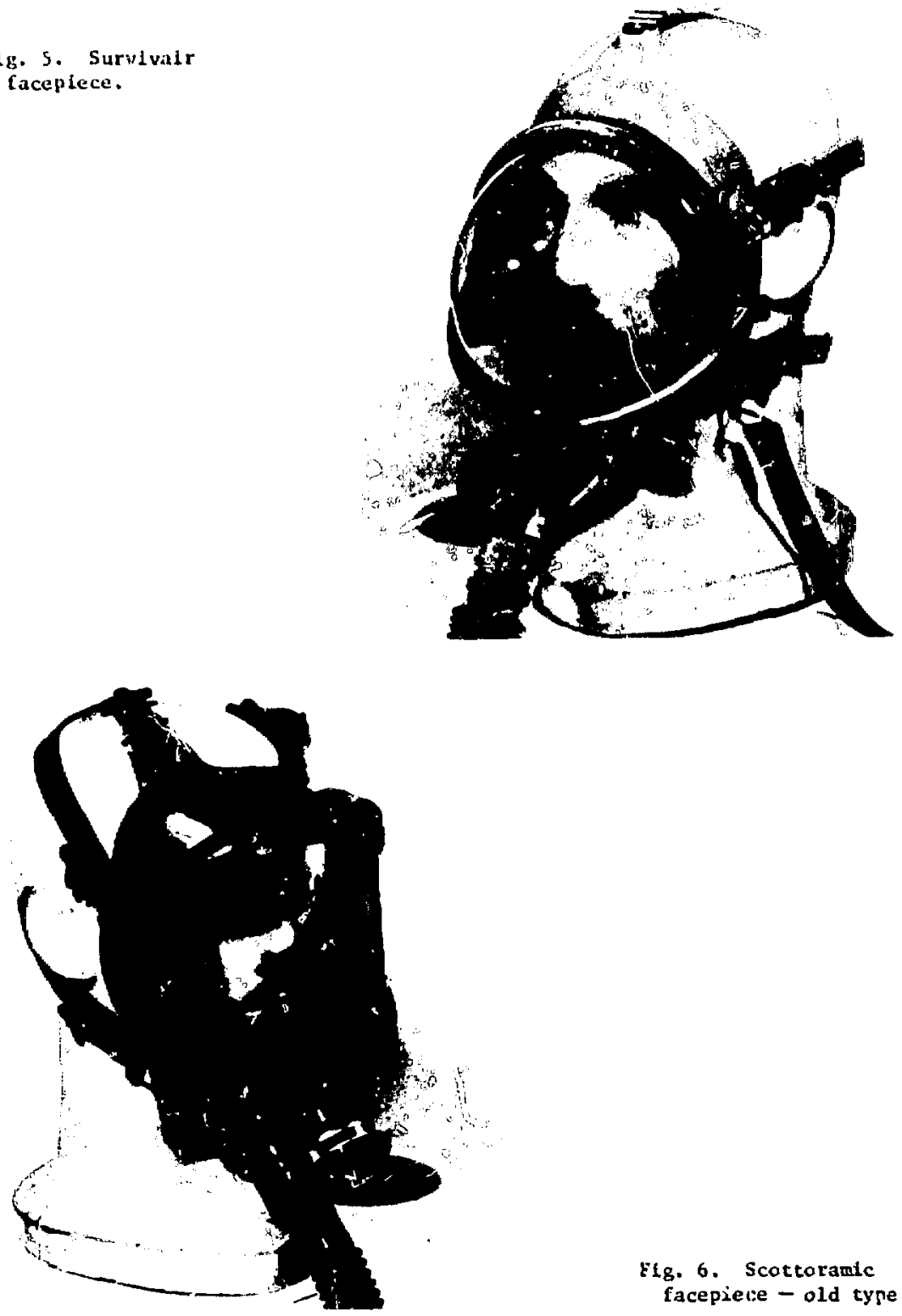

Efg. 6. Scottaramic facepiese - old type. 
Fig. 7. Welsh facepiece.
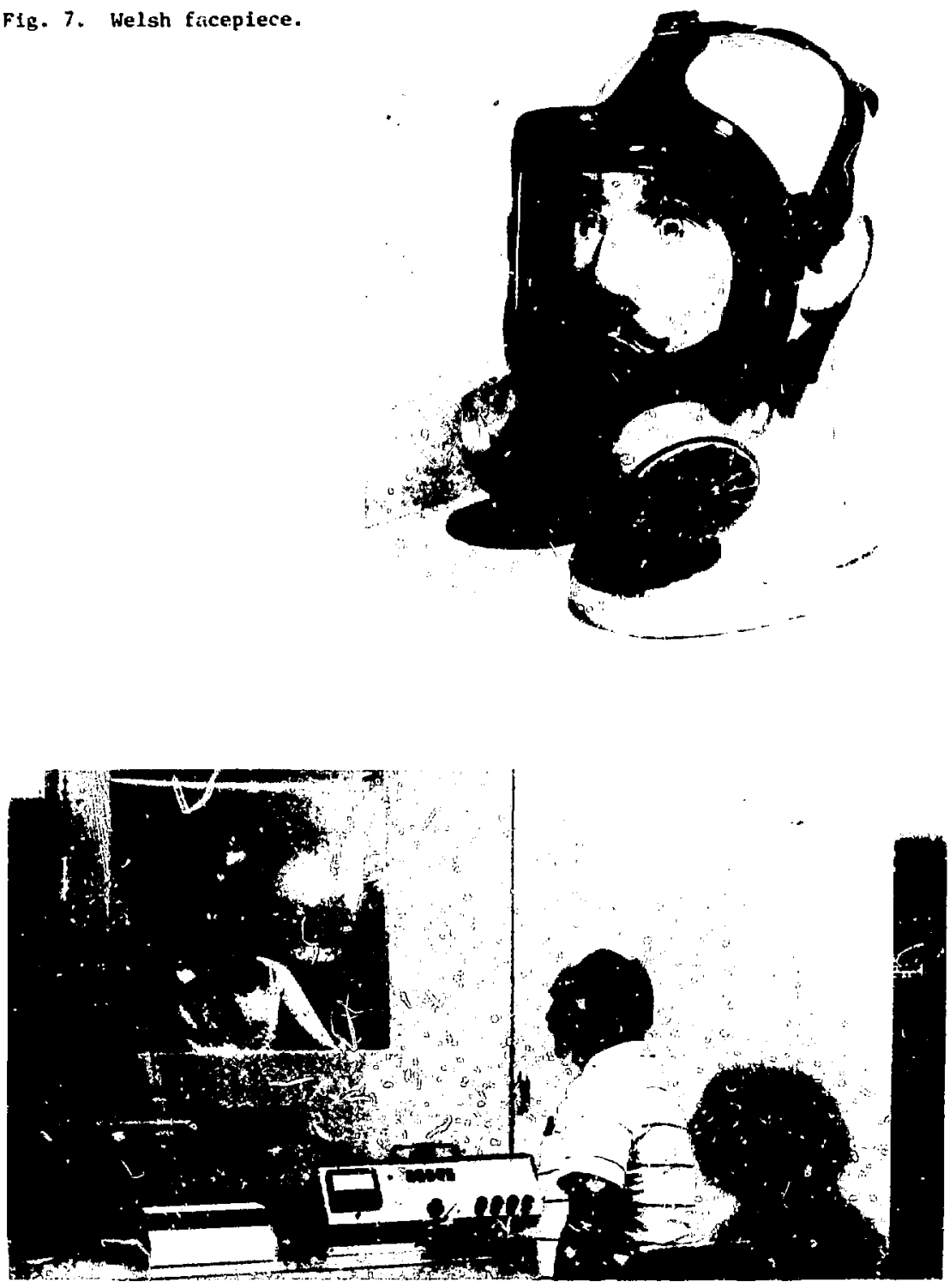

Fig. 8. Quantitative man-test fitting chamber and instrumentation. 


\section{Evaluation of Results}

Table 1 shows the results of 1362 yluantitative it tosts with selen nakes of tull-face supirat ... fhe mathimum use limits (ML'T.'s) werv whained by aking the in:egrated

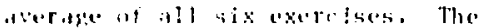
tosts bere made an bob tost subjecest. 'kit ol whom were tested on mote thon ane thake ot falceplece. Four ut the

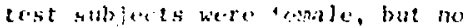
deficuley was exprerinticed in their whtaning setisfactory fit an at leatit une maki of maste. flften, the generall: smaller shape of the female dac will make it more difficule to fit a tull-face resniratur as the farpicos are usually siaed for fitting the average-sized inale face.

Tatble 2 is similar to rable 1, but shows, instead, the MUl. obtaired when the peak leakages from all exprises are averaged, rather than the integrated average leakage from all arercises.

The curiant. method of axriving a: a "pass/fall" $11 \mathrm{~m} 1 \mathrm{t}$ for a resplrator is that the average percent le kage for a full-faceplece must be $0.5 \%$, and that no peak for any exercise shall exceed $1.0 \%$. An MUL of 100 is then assigncd to the full-facepiece. An analysis of the data shows that the "pass/fall" criteria could bi:

lablo 1. Resulls of 1362 quantilative fit tests with seven makes of full-face respirators using integrated average maximum use $11 \mathrm{mit}$.

\begin{tabular}{|c|c|c|c|c|c|c|c|c|}
\hline \multirow[b]{2}{*}{$\begin{array}{l}\text { Make of } \\
\text { respirator }\end{array}$} & \multirow{2}{*}{$\begin{array}{l}\text { Number of } \\
\text { people tested } \\
\text { on eacl: make } \\
\text { of respirator }\end{array}$} & \multicolumn{7}{|c|}{$\begin{array}{l}\text { of people tested obtaining the ML as } \\
\text { indical od using integrate averages for } \\
\text { six exercises }\end{array}$} \\
\hline & & $<10$ & $\begin{array}{l}10- \\
100\end{array}$ & $\begin{array}{l}100- \\
500\end{array}$ & $\begin{array}{l}500- \\
1300\end{array}$ & $\begin{array}{l}1000- \\
2000\end{array}$ & $\begin{array}{l}2000- \\
5000\end{array}$ & $\begin{array}{l}5000 \mathrm{or} \\
\text { greater }\end{array}$ \\
\hline deme & 253 & 4 & 15 & 30 & 11 & B & 9 & 23 \\
\hline MSA Clearvue & 306 & 1 & 7 & 17 & 15 & 18 & 18 & 24 \\
\hline MSA vltravue & 222 & 4 & 4 & 20 & 17 & 18 & 18 & 19 \\
\hline Scatturamic-New & 139 & 2 & 29 & 22 & 11 & 5 & 10 & $2]$. \\
\hline Scottoramic-0ld & 185 & 7 & 14 & 21 & 15 & 16 & 18 & 9 \\
\hline Survivair & 19 & 0 & 11 & 5 & 26 & 11 & 21. & 26 \\
\hline lislsh & 238 & 6 & 14 & 28 & 8 & 13 & 11 & 30 \\
\hline
\end{tabular}


Table 2. Results of 1362 quantitative fit rests with seven makes of full-face respirators using peak average maximum use limit.

\begin{tabular}{|c|c|c|c|c|c|c|c|c|}
\hline \multirow[b]{2}{*}{$\begin{array}{l}\text { Nake of } \\
\text { cespiratcr }\end{array}$} & \multirow{2}{*}{$\begin{array}{l}\text { Number of } \\
\text { people tested } \\
\text { on cach make } \\
\text { of respirator }\end{array}$} & \multicolumn{7}{|c|}{$\begin{array}{l}\% \text { of people tested obtaining the MUL as } \\
\text { indiceted using peak averages for six exercises }\end{array}$} \\
\hline & & $\square 0$ & $\begin{array}{l}10- \\
100\end{array}$ & $\begin{array}{l}1,00- \\
500\end{array}$ & $\begin{array}{l}500- \\
1000\end{array}$ & $\begin{array}{l}1000- \\
2000\end{array}$ & $\begin{array}{l}2000- \\
5000\end{array}$ & $\begin{array}{l}5000 \text { or } \\
\text { greater }\end{array}$ \\
\hline Acme & 253 & 4 & 23 & 32 & 9 & 8 & 12 & 12 \\
\hline MSA Clearvue & 306 & 1 & 9 & 25 & 21 & 12 & 16 & 16 \\
\hline MSA Ultravue & 222 & 4 & 5 & 30 & 18 & 13 & 16 & 9 \\
\hline Scottoramic-New & 139 & 3 & 34 & 27 & 5 & 8 & 1.1 & 12 \\
\hline Scottoramic-01d & 185 & 8 & 17 & 29 & 15 & 17 & 11 & 3 \\
\hline Survivair & 29 & 0 & 16 & 16 & 16 & 21 & 5 & 26 \\
\hline \multirow[t]{2}{*}{ Welsh } & 238 & 5 & 16 & 23 & 12 & 13 & 10 & 21 \\
\hline & $1 \$ 62$ (total) & & & & & & & \\
\hline
\end{tabular}

changed to using fust the average of the peak leakages for all exercises if it does not exceed $1 \%$ (NUL $\geq 100$ ). Since a user's average exposure is the integrated average of all exercises, the average of the peaks obtained in all exercises is still conservative. One number for the "pass/fail" criterion wauld be easier to use than the current system of two numbers.

The analysis also shows that if a user is not permitted to wear any full facepiece that does not give him a MUL of at least 100 , he could wear those devices, within the capabilities of the cartridges or canisters, up to the maximum MUL he had obtained on those facepieces. Since only the peak averages are used to determine the user's MUL, a safety factor is still built in to account for not donning the facepiece in an identical manne: each time.

Table 3 shows the highest MUL obtainable on 284 people who were fitted with two or more full-facepleces. In most cases, at least four different full-facepieces were tested. Every person tented could get at least one make of facepiece which gave him or her a MUL over 100. Using the peak averages for all six exercises, $81 \%$ of thost fitted obtained a MUL of 1000 or greater, of which $44 \%$ were over 5000 .

Table 4 gives the percent of times in which different makes of full-face respirators were the best and the 
Table 3. Highest maximum use limit obtained on 284 people who were fitted with two or more full-face respirators.

\begin{tabular}{|c|c|c|c|c|}
\hline \multirow[b]{2}{*}{$\begin{array}{l}\text { Best MUL } \\
\text { obtained }\end{array}$} & \multicolumn{2}{|c|}{ Total number of people } & \multicolumn{2}{|c|}{$\%$ of people } \\
\hline & $\begin{array}{l}\text { Peak ave. } \\
\text { for six } \\
\text { exercises }\end{array}$ & $\begin{array}{c}\text { Integrated } \\
\text { ave. for } \\
\text { six } \\
\text { exercises }\end{array}$ & $\begin{array}{c}\text { Peak ave. } \\
\text { for six } \\
\text { exercises }\end{array}$ & $\begin{array}{l}\text { Integrated } \\
\text { ave. for } \\
\text { aix } \\
\text { exercises }\end{array}$ \\
\hline$<100$ & 0 & 0 & 0 & 0 \\
\hline $100-500$ & 22 & 5 & $8 \%$ & $2 \%$ \\
\hline $500-1000$ & 32 & 22 & $11 \%$ & $8 \%$ \\
\hline $1000-2000$ & 36 & 29 & $13 \%$ & $10 \%$ \\
\hline $2000-5000$ & 70 & 52 & $24 \%$ & $18 \%$ \\
\hline $5000 \&$ greater & 124 & 176 & $44 \%$ & $62 \%$ \\
\hline
\end{tabular}

Table 4. Percent of times in which different makes of full-face respirators were the best or poorest fitting on people who were fitted with two or more masks.

\begin{tabular}{llll}
\hline & $\begin{array}{l}\text { No. of people } \\
\text { fitted with this } \\
\text { make (two or } \\
\text { more different } \\
\text { masks used) }\end{array}$ & $\begin{array}{l}\text { \% of time when } \\
\text { this make gave } \\
\text { best fit }\end{array}$ & $\begin{array}{l}\% \text { of time when } \\
\text { this make gave } \\
\text { poorest fit }\end{array}$ \\
\hline Ac.ne & 253 & 19 & 26 \\
MSA Clearvue & 284 & 29 & 11 \\
MSA Ultravue & 222 & 23 & 7 \\
Scottoramic "New" & 139 & 11 & 53 \\
Scottoramic "Old" & 185 & 14 & 28 \\
Survivaix & 19 & 26 & 11 \\
Welsh & 238 & 24 & 19 \\
\hline
\end{tabular}


poorest fitting on the 284 employees who were fitted with two or more masks. Again, in most cases, each person was fitted with at least four different makes of masks. The MSA Clearvue, the MSA Ultravue, the new Scottoramic, the old Scottoramic, and the Survivalr masks wete fitted on those peorle who use or may have occasion to use self-contained breathing apparatus (SCBA). The Survivatr faceplece was only fitted on 19 people as this mask was just. obcained In June 1976. * The Acme, MSA Clearvue, MSA Ultravue, and the Welsh facepleces were fitted on people who use or may have occasion to use air-purlfying full-facepieces.

For SCBA facepleces, the two MSA facepieces not only gave the best fit to the greatest number of people,

Thirty firefighters have since been fitted with the Survivair facepiece, and the results are shown in the Append 1x. but also gave the poorest fit to the fewest number of people. The Survivair facepiece performed well, based on the low number of people on which it has been tested.

A special internal report has been prepared on the SCBA program at LLL. Portions of this report are included in the App 'ndlx for addttonal information. The differences in the fitting of the four air-purifying facepleceb were not as dramatic as with the SCBAs.

Table 5 shows the first and second choices of facepieces from 196 employees who were fitted with four or more different makes of ful]-facepieces. The choices were made on comfort only wthout the test subfect knowing whether or not the mask gave a good fit. As far as the Laboratory employees were concerned, the two MSA and the Welsh facepieces were by far the most popular. For those tested, the Survivair facepiece was also well received. 
Table 5. First and second choices of 196 test subjects who were fitted with: four or more full-face resplrators.

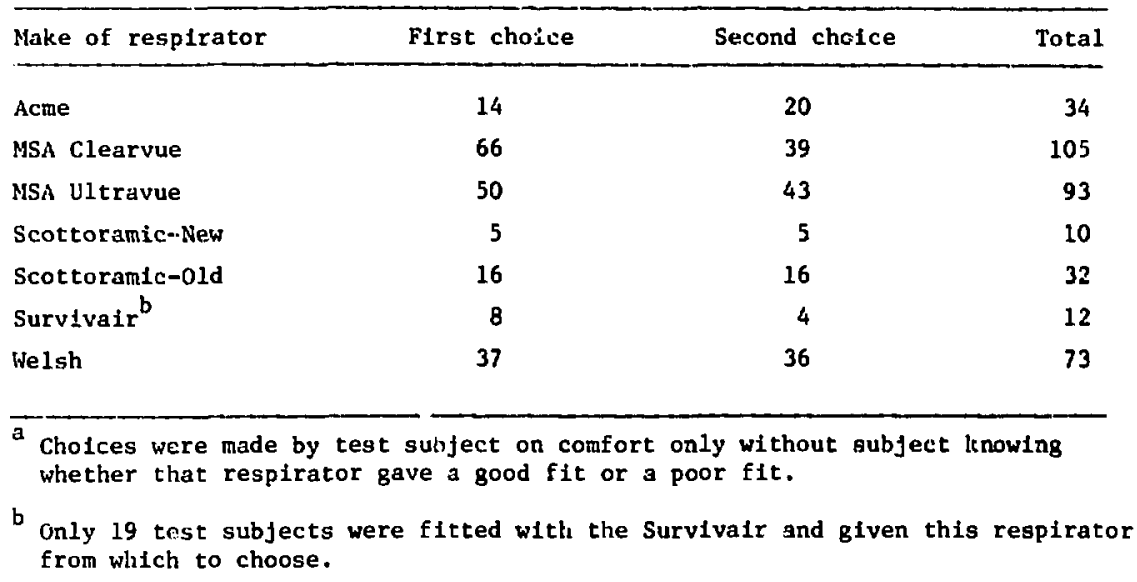

\section{Conclusions}

It is concluded that the "pass/ fail" criteria for full facepieces can be based just on the peak leakages for all exercises. A user should not be permitted to use a respirator that does not give him a MUL of at least 100 , but should be permitted to wear a device, within the capabilities of the cartridges or canisters, up to the maximum MUL he has obtained on that device.

\section{Refc:ences}

1. "Resplratory Protection Manual, Supplement 10.05," Bealth and Safety Mamual, Lawrence Livermore Laboratory, University of California (Feb. 1977).

2. Hazards Contsiul Progress Report No. 51, July through December, 1975, Lawrence Livermore Laboratory, University of California (1976). 


\title{
Appendix A \\ A Study of Lawrence Livermore Laboratory Self-Contained Breathing Apparatus Program
}

\author{
Bruce J. Held and Charles P. Richards
}

QUANTITATIVE FITTIXG RLSUI.TS

Table A-1 lists che results of the quant liative fitcing tests on the firefighters in groups, according to the percent of loakige occurring. Table A-2 shows the restits for tach firefighter with the actul anount of leakage occurring with each facepiece tested.

The Scott 6000 serles mask that had been altered to accomadite the Metrotech Commundeations lind gave a very poor fit eo most of the firefinluters. This was as expected, since the Metrotech has to be mounted on the right or left side of the faceplece. The Netrotech liself is quite heavy, and chts additional wefght on only one side of the mask distorts the shape of the faceplece, causing it to leak.

Table A-1. Results of quantitative fitting tests on I.LL IIrafighters wits (Ive makes of full-face resplrators and a Scott. 6000 serles mask fitred with a Metrotech Commurications Unit using the penk average percent leakage on $\mathrm{six}$ exercises.

\begin{tabular}{|c|c|c|c|}
\hline Type of faceplece & $\begin{array}{l}\text { No. of } \\
\text { firefighters with } \\
<1 \% \text { facepiece } \\
\text { leakage }\end{array}$ & $\begin{array}{l}\text { No. of } \\
\text { firefighters with } \\
1-5 \% \text { faceplece } \\
\text { leakage }\end{array}$ & $\begin{array}{c}\text { Ho. of } \\
\text { flrefighters with } \\
\times 5 \% \text { ficeplece } \\
\text { leakage }\end{array}$ \\
\hline MSA Clearvue & 28 & 2 & 0 \\
\hline MSA U1travue & 29 & 1 & 0 \\
\hline $3 \cot t 6.000$ faceplece & 18 & 9 & 3 \\
\hline Scott 9000 faceplece & 9 & 18 & 2 \\
\hline Survivair & 24 & 5 & 1 \\
\hline $\begin{array}{l}\text { Scott } 6000 \text { faceplece } \\
\text { with Metrotech Unit }\end{array}$ & 10 & 16 & 4 \\
\hline
\end{tabular}


Table A-2. Ficting results of the L.l. firefightera by individual ScBa facepleces.

7 Iaceplece leakage - peak averages for all exercises

\begin{tabular}{|c|c|c|c|c|c|c|}
\hline $\begin{array}{l}\text { Firefighter } \\
\text { test subject no. }\end{array}$ & $\begin{array}{l}5 \cot t \\
6000\end{array}$ & $\begin{array}{l}\text { Scote ulth } \\
\text { Metrotech } \\
6000\end{array}$ & $\begin{array}{l}\text { Scote } \\
9000\end{array}$ & $\begin{array}{c}\text { MSA } \\
\text { vleravue }\end{array}$ & $\begin{array}{c}\text { MSA } \\
\text { Clearvue }\end{array}$ & Survivalr \\
\hline 1 & 0.25 & 0.33 & 3.2 & 0.1 & 0.03 & 0.04 \\
\hline 2 & 0.27 & 4.4 & 2.0 & 0.09 & 0.04 & 0.44 \\
\hline 3 & 0.1 & 0.12 & 9.0 & 0.33 & 0.12 & 0.07 \\
\hline 4 & 3.3 & 4.7 & 4.2 & 1.5 & 0.50 & 2.1 \\
\hline 5 & 0.62 & 20.0 & 3.0 & 0.30 & 0.20 & 0.34 \\
\hline 6 & 29.0 & 24.0 & 0.23 & 0.65 & 0.05 & 0.13 \\
\hline 7 & 0.6 & 3.3 & 3.1 & 0.3 & 0.10 & 0.09 \\
\hline 8 & 3.5 & 5.0 & 3.4 & 0.2 & 0.36 & 0.18 \\
\hline 9 & 0.3 & 0.2 & 0.6 & 0.45 & 0.01 & 0.17 \\
\hline 10 & 0.7 & 0.60 & 0.3 & 0.05 & 0.04 & 0.02 \\
\hline 11 & 4.11 & 4.8 & 3.7 & 0.18 & 0.1 & 0.22 \\
\hline 12 & 1.0 & 0.4 & 3.2 & 0.2 & 0.15 & 0.02 \\
\hline 13 & 4.4 & 2.4 & 0.5 & 0.06 & 0.02 & 0.01 \\
\hline 14 & 1.4 & 4.6 & 0.2 & 0.1 & 0.14 & 0.01 \\
\hline 15 & 0.2 & 1.2 & 4.5 & 0.7 & 0.3 & 0.24 \\
\hline 16 & 0.01 & 0.56 & 0.12 & 0.2 & 0.02 & 0.33 \\
\hline 17 & 0.1 & 1.28 & $6: 9$ & 0,2 & 0.2 & $0 . \overline{v i}$ \\
\hline 18 & 0.1 & 09 & 0.3 & 0.03 & 0.8 & 3.2 \\
\hline 19 & 3.2 & 2.5 & 1.7 & 0.3 & 0.3 & 1.1 \\
\hline 20 & 0.13 & 0.92 & 1.2 & 0.55 & 0.02 & 0.07 \\
\hline 21 & 2.1 & 3.4 & 1.9 & 0.42 & 1.4 & 1.2 \\
\hline 22 & 8.4 & 2.2 & 2.6 & 0.6 & 0.5 & 1.3 \\
\hline 23 & 0.4 & 1.0 & 0.8 & 0.4 & 0.1 & 0.23 \\
\hline 24 & 0.1 & 1.6 & 0.1 & 0.01 & 0.06 & 0.08 \\
\hline 25 & 7.0 & 0.36 & - & 0.23 & 1.7 & 0.57 \\
\hline 26 & 0.07 & 1.9 & 1.9 & 0.37 & 0.01 & 0.48 \\
\hline 27 & 0.7 & 6.9 & 3.8 & 0.50 & 0.09 & 0.30 \\
\hline 28 & 0.7 & 0.8 & 4.4 & 0.6 & 0.04 & 0.20 \\
\hline 29 & 1.7 & 4.2 & 4.5 & 0.3 & 0.3 & 8. 3 \\
\hline 30 & 0.1 & 4.0 & 4.4 & 0.1 & 0.01 & 0.21 \\
\hline
\end{tabular}


Table A-3 siows the peresent of time each type of mask was the best fitting and the poorest fitting on the flrefighters. Hased on fiteing alone, the ISA Clearvue is by far the best fil: ing mask wth the lif. Fl Fe Department personnel. of an added advantage Is the fact that the issileravue can be used on the sane 401 SCBd unit, thus giving an option of us Ing two types of ansks on the same untt. No ocher ScBA unit has this option. It should be further noted that the two firefighters who had a leakage between $1-2 \%$ un the MSA Clearvie got their hist fit on the MSA Ultravtie.

\section{Cosprokt}

Each firofighter being fitced was asked at whe end of the session which cype of facoplece he preferred, partleutarly In regrid to comfort. Twentyseven of them pave a first and some a second cholce; the remalnder efther found nore of them comfortable or had no preference. Table $\boldsymbol{A}^{-4} 11 \mathrm{sts}$ the preferences of the firefighters who had an option. While there wis no overwhelaing favortte. the Survivalr mask received the greatest number of flrst and second choices. The other four masks all scored about equally.

Table -3. Percent of times in whlch the ftve makes of masks were the best or the poorest fitting.

\begin{tabular}{|c|c|c|}
\hline Type of facepiece & $\begin{array}{l}\text { 7. of time when } \\
\text { this type of facepiece } \\
\text { gave the best it of } \\
\text { the five types cested }\end{array}$ & $\begin{array}{l}\text { \% of time when } \\
\text { this type of facepicce } \\
\text { gave the poorest fte of } \\
\text { che flve types tested }\end{array}$ \\
\hline MSA Clearvue & 587 & 0 \\
\hline YSA Ulteravue & $15 \%$ & 0 \\
\hline$S \cot t 6000$ facepiece & $3 \%$ & $35 \%$ \\
\hline Scott 9000 faceplece & 0 & $55 \%$ \\
\hline Survivair & $24 \%$ & $10 \%$ \\
\hline
\end{tabular}

a Tle results were counted in favor of both types of masks. 
1.thle i-4. Proference of twenty-seven firefighters on which of five facepleces they folt most comfortable.

Type of facepleic

First cholce

Second cholce

SSA Clearvue

6

2

צti literisute

3

6

seotecramic "old"

6

2

Srottarianla "New"

s

5

survivilr

;

6

" These preferences were stated without the firefighters being tested knowing which farcelece gave him a satisfactory fit.

\section{ANTHROPONETHIC SURVEY}

To sce if nur fitting results were Influenced at all by having Fire bepartment personnel with different faclal sizes than would nornally be expected with an alult mile popuiation, face length and face width measurements were made on mineteen of the firefighters. In general, the LLL Fire Department personnel wert very slightly skawed toward having, overall, longer faces than the average adult male population in the AIr Force and LASL studies. However, the difforences were not great enough to have any effect on the overall fitting characteristics of the individuals tester.. 